\title{
各種モノグリセリド中で加熱処理した澱粉の特性
}

\author{
伊藤友美 ${ }^{\S}$, 安達卓生*, 小原章裕*, 山田哲也* \\ 愛知みずほ大学 \\ *名城大学農学部
}

\section{Changes in Properties of Starches Heated in Monoglycerides}

\author{
Tomomi Ito ${ }^{\S}$, Takuo Adachi*, Akihiro Ohara* and Tetsuya Yamada* \\ Aichi Mizuho College, 86-1 Haiwa, Hiratobashi-cho, Toyota, Aichi 470-0394 \\ *Faculty of Agriculture, Meijo University, 1-501 Shiokamaguchi, \\ Tenpaku-ku, Nagoya, Aichi 468-8502
}

\begin{abstract}
Property changes in three varieties of starch (normal corn, waxy corn and wheat) heated in three varieties of monoglycerides (glycerin monostearate (MS), glycerin monooleate (MO) and glycerin monolinolate (ML)) were investigated. The starches were heated at $150^{\circ} \mathrm{C}$ for $1 \mathrm{~h}$ under open-air conditions. The heated starches were thoroughly washed with chloroform and dried. Little change in the shape of starch granules in all samples was observed on SEM images. Differential scanning calorimetry patterns were different among the starch and monoglyceride varieties with the decrease in enthalpy ratios compared to the control being $31 \%$ for normal corn starch in ML ; $20 \%$ for waxy corn starch in ML ; and $8 \%$ for wheat starch in ML. Rapid visco-analyzer patterns were different among the starch and monoglyceride varieties with the maximum viscosity peak ratio compared to the control being $2 \%$ for normal corn starch in ML; $0 \%$ for waxy corn starch in ML; and $8 \%$ for wheat starch in ML. The extent of amylose degradation was different among starch samples : 65\% for normal corn starch in ML and 43\% for wheat starch in ML. Gel permeation chromatography using a Toyopearl HW-65 column showed only one sharp peak in all the patterns of starch samples heated in ML, indicating amylopectin decomposition products with an average molecular weight of 1800 . In contrast to the results of ML, changes in starch properties were small in the samples heated in MS. These results suggest that monoglycerides might easily penetrate into starch granules, forming radicals in an unsaturated fatty acid moiety with heating, and these starch components might be directly and/or indirectly attacked by these radicals and decompose to a dextrin-sized product.
\end{abstract}

(Received Jun. 23, 2008 ; Accepted Aug. 13, 2008)

Keywords : heat treatment, monoglyceride, starch

キーワード：モノグリセリド，乾熱処理，激粉特性

澱粉性食品の製造では, 澱粉糊化のため一般に水存在下 で加熱処理がなされる。 その際, 品質向上の目的で界面活 性剂が用いられ，これが糊化澱粉と包摂することで老化防 止などの効果が発揮されると言われている(1)2).

糊化とは，熱と水の作用で澱粉粒が膨潤，崩壊（水和） する現象をいい, 生澱粉に比べて消化 (分解) されやすい ため食品加工において澱粉を糊化することは重要であ る ${ }^{3)}$. しかし，クッキーなど小麦粉焼成菓子では低水分含 量や高油脂含量などにより糊化が抑制される ${ }^{4) 5)}$. 我々は先 に水分を殆ど含まず，種々の油脂を多く含有したクッキー 様組成の生地を作製し, これを焼成した時の油脂の種類に

₹470-0394 愛知県豊田市平戸橋町波岩 86-1

* 干468-8502 愛知県名古屋市天白区塩釜口 1-501

$\S$ 連絡先 (Corresponding author), ito-to@mizuho-c.ac.jp
よるクッキー様菓子中の澱粉特性の变化を検討した ${ }^{6)}$. そこで今回は, この機構解明を目的に, 水がほとんど存 在しない高温環境下で界面活性剂（モノグリセリド）が澱 粉特性に与える影響を, 界面活性剂と澱粉の種類を变えて 検討した。

\section{実 験 方 法}

\section{1. 試 料}

試料澱粉は，グリコ栄養食品株式会社製の小麦澱粉およ び日本食品化工株式会社製のウルチ種とモチ種のとうもろ こし澱粉を使用した。

界面活性剂（モノグリセリド）は理研ビタミン株式会社 製のエマルジー MS (脂肪酸組成 $(\%)$ : ステアリン酸 68 , パルミチン酸 30 , ミリスチン酸 2 ), エマルジーOL（脂肪 

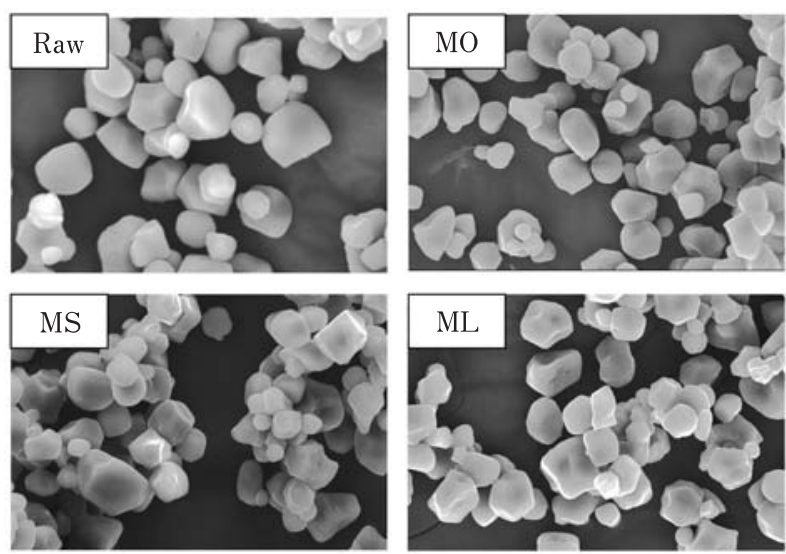

Fig. 1 Scanning electron micrographs of normal corn starch heated in monoglyceride Images were taken with 1000 fold of magnification

酸組成 $(\%)$ : オレイン酸 80 , パルミチン酸 10, ステアリ ン酸 5 , リノール酸 5), エマルジー MU (脂肪酸組成 (\%) : リノール酸 75 , パルミチン酸 10 , オレイン酸 10 , ステアリ ン酸 5）の 3 種類のモノグリセリドを用いた。. 以後エマル ジーMSを MS, エマルジー OLを MO, エマルジーMUを ML と示す.

\section{2. 試料調製}

あらかじめ各種モノグリセリドを $150^{\circ} \mathrm{C}$ 中で液状にし， そこへ各種澱粉を加えて $150^{\circ} \mathrm{C} ， 1$ 時間加熱処理を行った. これを冷却後, クロロホルムを加えて脱脂, 乾燥し, 試料 澱粉とした.

\section{3. 走査型電子顕微鏡観察}

各試料澱粉を日立イオンスパッター（E-1010 日立製）で Au-Pt 蒸着処理後, 走査型電子顕微鏡 (S-3000H 型 日立製) を用いて 1000 倍で観察した。

4. 示差走査熱量分析測定 (DSC)

各試料澱粉を前報6) に準じ, DSC6100（セイコー製）で 測定した。

5. ラピッドビスコアナライザー $(\mathrm{RVA})^{7)}$

各試料澱粉に蒸留水を加えて $5 \%$ 澱粉懸濁液（水分補正） にし, 糊化特性試験装置 RVA（ニューポートサイエンティ フィック社製) で測定した。測定条件は前報6)に準じた。

\section{6. $\exists$ ウ素澱粉反応測定 ${ }^{8)}$}

各試料澱粉を前報 ${ }^{6)}$ に準じて吸収スペクトルを測定し, 各スペクトルから最大吸收波長（入 max）を求めた。また $680 \mathrm{~nm}$ の吸光度とフェノール-硫酸法 ${ }^{9)}$ で求めた試料溶液 の全糖量から，青価（Blue value）を算出した。

\section{7. ゲルろ過クロマトグラフィー（GPC）}

前報6)に準じ，ゲルは Toyopearl HW-65F で GPC を行っ た. 溶出液と試料溶液の全糖量をフェノール-硫酸法 ${ }^{9)}$ で定 量し, 溶出パターンを求めた。
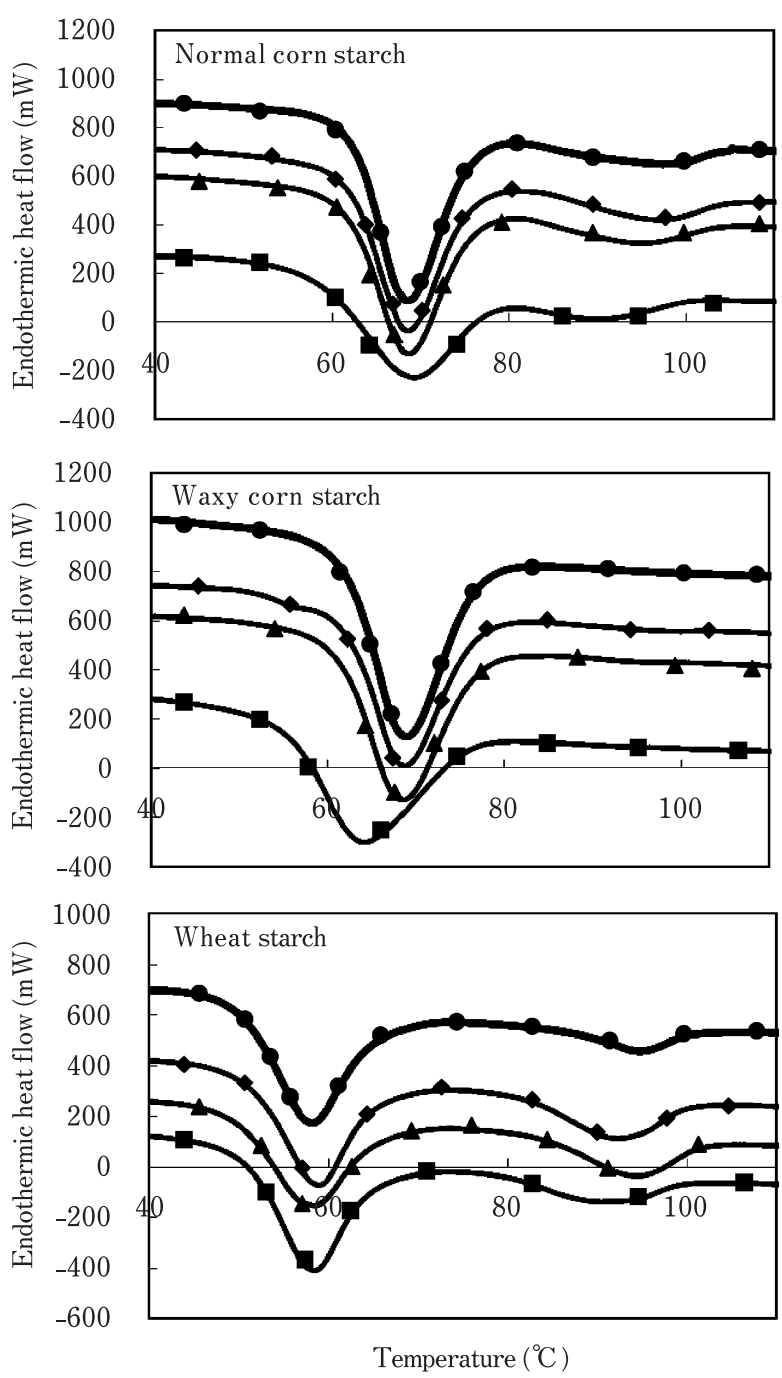

Fig. 2 Differential scanning calorimetry thermograms of starch heated in monoglyceride

- Raw starch; $\diamond$, Starch heated in MS

$\boldsymbol{\Delta}$, Starch heated in MO ; $\mathbf{\square}$, Starch heated in ML

\section{実験結果および考察}

\section{1. 澱粉粒の観察}

3 種類のモノグリセリド中で加熱処理した澱粉粒と生澱 粉粒を走査型電子顕微鏡（SEM）で観察した結果，よ゙の加 熱処理澱粉粒も生澱粉粒との違いは認められなかった。ウ ルチ種のとうあろこし澱粉のみ Fig. 1 に示した. このこと から，モノグリセリド中で加熱処理した澱粉粒は糊化膨化 していないことがわかる.

\section{2. 糊化特性}

3 種のモノグリセリド中で加熱処理した各種澱粉と生澱 粉の示差走査熱量測定 (DSC) 結果を Fig. 2 と Table 1 に 示した。加熱処理したウルチ種のとうあろこし澱粉におい て，第一ピークの $\mathrm{Tp}$ 温度は， $68^{\circ} \mathrm{C}$ 付近で変化はみられな いが，そのエンタルピーは生澱粉に比べて 10〜30\%小さ 
Table 1 Thermal properties of starch heated in monoglyceride

\begin{tabular}{cccccccc}
\hline \hline & \multicolumn{5}{c}{ Peak 1} & & \multicolumn{2}{c}{ Peak 2} \\
\cline { 2 - 3 } \cline { 7 - 8 } & $T_{0}\left({ }^{\circ} \mathrm{C}\right)$ & $T_{\mathrm{p}}\left({ }^{\circ} \mathrm{C}\right)$ & $T_{\mathrm{c}}\left({ }^{\circ} \mathrm{C}\right)$ & $\Delta H(\mathrm{~mJ} / \mathrm{mg})$ & & $T_{\mathrm{p}}\left({ }^{\circ} \mathrm{C}\right)$ & $\Delta H(\mathrm{~mJ} / \mathrm{mg})$ \\
\hline Normal corn starch & & & & & & & \\
Raw & 62.7 & 68.4 & 79.9 & 12.36 & & 97.3 & 1.76 \\
Heated in MS & 61.6 & 68.6 & 80.5 & 11.25 & & 97.1 & 2.27 \\
Heated in MO & 61.6 & 68.6 & 80.1 & 11.30 & & 94.9 & 2.05 \\
Heated in ML & 57.8 & $69 . .1$ & 80.3 & 8.53 & & 90.1 & 1.50 \\
Waxy corn starch & & & & & & - \\
Raw & 61.4 & 68.8 & 82.8 & 15.02 & & - & - \\
Heated in MS & 61.5 & 68.7 & 82.8 & 11.86 & & - \\
Heated in MO & 60.8 & 68.2 & 82.1 & 13.27 & & - & - \\
Heated in ML & 55.0 & 63.8 & 80.1 & 12.08 & & - & - \\
Wheat starch & & & & & & \\
Raw & 50.4 & 58.1 & 73.1 & 9.64 & & 94.8 & 1.59 \\
Heated in MS & 49.8 & 58.3 & 72.9 & 7.89 & & 94.3 & 3.33 \\
Heated in MO & 50.3 & 58.7 & 72.3 & 8.38 & & 92.1 & 3.49 \\
Heated in ML & 49.7 & 58.5 & 72.7 & 8.91 & & 90.5 & 2.40 \\
\hline
\end{tabular}

DSC analysis condition ; $\operatorname{pan}(\mathrm{Ag}), 70 \mu 1$; sample, $15 \mathrm{mg}$; water, $45 \mu 1$; heating rate, $2^{\circ} \mathrm{C} / \mathrm{min}$. $T_{\mathrm{o}}$, onset temperature ; $T_{\mathrm{p}}$, peak temperature ; $T_{\mathrm{c}}$, conclusion temperature ; $\Delta H$, enthalpy .

くなった. 一方，第二ピークの $\mathrm{Tp}$ 温度は生澱粉に比べて MS, MO, ML の順に低くなり, そのエンタルピーは变化 がみられなかった。

モチ種のとうもろこし澱粉において，第一ピークの $\mathrm{Tp}$ 温度は, $\mathrm{ML}$ が $63.8^{\circ} \mathrm{C}$ と生澱粉の $68.8^{\circ} \mathrm{C}$ に比べて顕著に下 がったが，MS，MOでは変化がみられなかった。しかし， そのエンタルピーは, 生澱粉に比べて 10〜20\%小さくなっ た. 第二ピークはアミロースの包摂に起因すると言われてい るため, アミロースを欠除するモチ種ではみられなかった。

小麦澱粉において, 第一ピークの $\mathrm{Tp}$ 温度は $58^{\circ} \mathrm{C}$ 付近 でとうもろこし澱粉の場合と同様に生澱粉とモノグリセリ ド中で加熱処理した各種澱粉との間に差はみられないが, そのエンタルピーは生澱粉に比べて 15〜20\%小さくなっ た。また，第二ピークの Tp 温度は，生澱粉に比べて $\mathrm{MS}$, MO, ML の順に低温にシフトし, そのエンタルピーは生澱 粉と比べて 1.5〜2 倍も大きくなった.

このようにウルチ種のとうもろこし澱粉と小麦澱粉の第 2 ピークのエンタルピーが生澱粉に比べて大きくなってい ることから，モノグリセリド中で加熱したことにより澱粉 内でモノグリセリドの包摂が起こっていることが考えられ る. また, MS, MO に比べて ML のエンタルピーが小さい ことから，脂肪酸の不飽和度が上がるほよ゙，包摂量が減少 していると思われる。飽和脂肪酸は複合体を形成し易く ${ }^{10)}$,

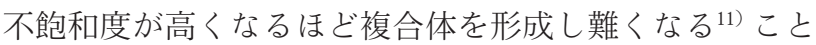
から，今回の結果と一致した。しかし，一般に食品でのモ ノグリセリドの場合，複合体形成は水と熱による港粉の糊 化と同時進行的に起きるが，今回の実験結果から低水分の 状態でも複合体が形成されることが判明した。

\section{3. 粘度特性}

3 種のモノグリセリド中で加熱処理した各種澱粉と生澱 粉の粘度特性をラピッドビスコアナライザー（RVA）で測 定した結果を Fig. 3 に示した。 また, 最高粘度, 最低粘度, 最終粘度および $50^{\circ} \mathrm{C}$ から $95^{\circ} \mathrm{C}$ の昇温保持まで（測定時間 60-432 秒の間) のピーク面積と $95^{\circ} \mathrm{C}$ から $50^{\circ} \mathrm{C}$ の降温保持 まで（測定時間 433-780 秒の間）のピーク面積を Table 2 に示した.

どの澱粉においても MS，MO，ML の順に粘度が低下し ており，ウルチ種のとうむろこし澱粉では最高粘度が生澱 粉に比べてそれぞれ $90 \%, 21 \%, 2 \%$ ，モチ種のとうあろこ し澱粉ではそれぞれ $32 \% ， 3 \% ， 0 \%$ ，小麦澱粉ではそれぞ れ 38\%，29\%，8\%であった。この生澱粉に対するピーク 粘度の割合は, 最高粘度と $50^{\circ} \mathrm{C}$ から $95^{\circ} \mathrm{C}$ の昇温保持まで (測定時間 60-432 秒の間) のピーク面積に相関がみられた。 また，澱粉の種類によって後述の様に粘度特性が異なる挙 動を示した。

ウルチ種のとうあろこし澱粉において，最高粘度で比較 すると，MS は生澱粉よりやや低い $90 \%$ であるが，MO は $25 \%$ と生澱粉に比べて著しく粘度が低下しており，MLに おいては殆ど粘度を示さなかった。

モチ種のとうもろこし澱粉において，MS は生澱粉に比 べて最高粘度に達するまでの時間が遅く， 2 段階で粘度が 上がっていた。 また，降温過程で粘度が増し，最終粘度は 生澱粉より $32 \%$ 屯高くなった。 MO および MLにおいて はそれぞれ 1.0 RVU，0.1 RVU と殆ど粘度がなかった。

小麦澱粉では，最高粘度，最低粘度および最終粘度が生 澱粉に比べ，それぞれ MS では 38\%，44\%，57\%，MO で 

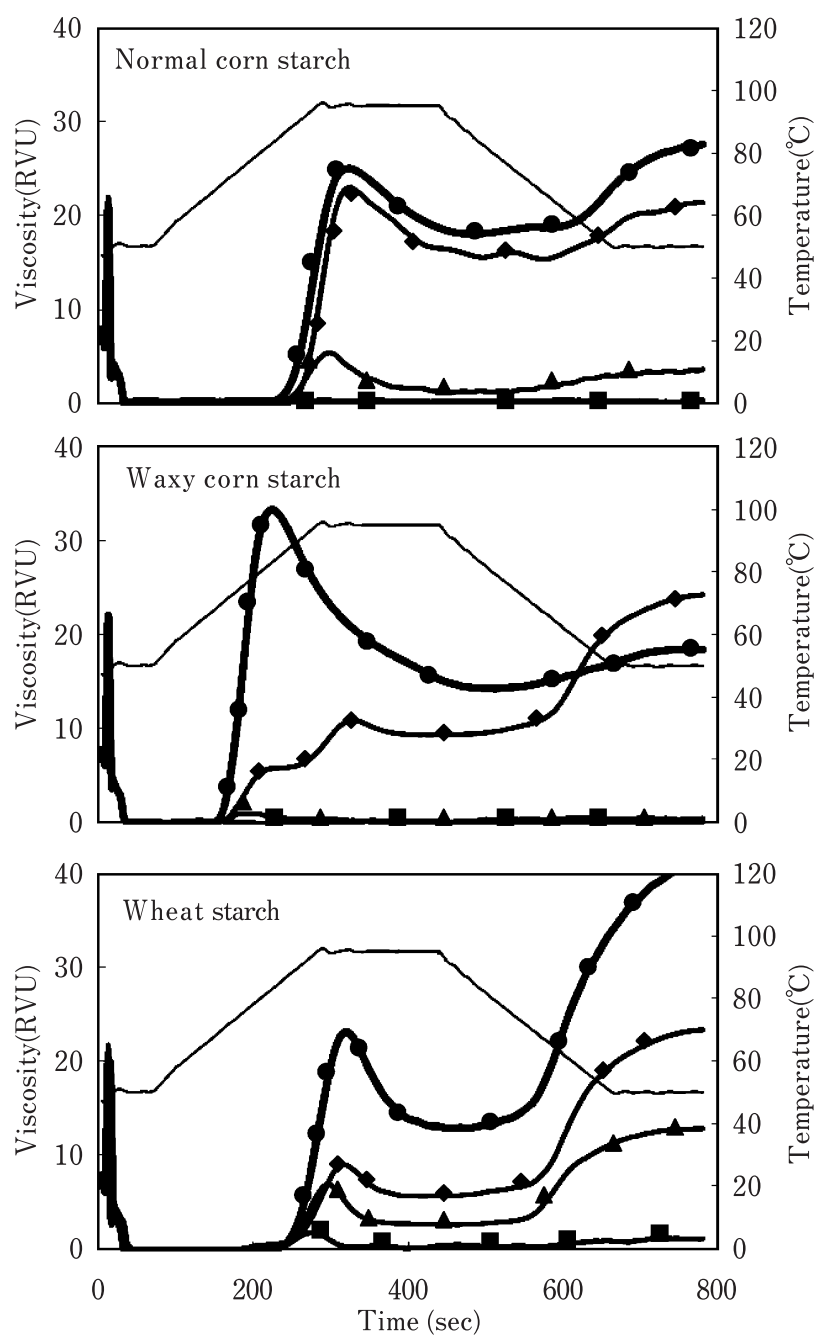

Fig. 3 Rapid viscogram patterns of starch heated in monoglyceride

- Raw starch; $\diamond$, Starch heated in MS

$\boldsymbol{\Delta}$, Starch heated in MO ; $\mathbf{\square}$, Starch heated in ML

-, Temperature

は $29 \%, 20 \%, 31 \%, \mathrm{ML}$ では $8 \%, 3 \% ， 3 \%$ と不飽和度 が高くなるほど低下していた。

このように飽和脂肪酸主体の MS は, 澱粉の種類によっ て特徵的な挙動を示した。なお，MS は常温固体だが，あ らかじめ加熱して液状にしてから澱粉を処理しているた め，熱媒体の差ではないと思われる。

一般に脂質は澱粉の糊化膨潤に大きな影響を及ぼし，粘 度を低下させることは知られているが12), 不飽和度が高く なるほど粘度が低下することが明らかになった。粘度特性 は分枝構造をむつ巨大分子の澱粉中のアミロペクチンに影 響されることから，モノグリセリド中で加熱処理したこと により，澱粉中のアミロペクチンが分解され低分子化した ことが示唆される。

しかし，モノグリセリドが単なる熱媒体として働いてい るだけなら，どのモノグリセリドにおいても同様な結果が
予測されるが，Fig. 3 に示した様に全く異なる挙動をして いることは，モノグリセリドの構成成分の脂肪酸が糊化挙 動に関与していることを示している，食品にモノグリセリ ドを用いる目的の一つに糊化した澱粉の老化防止があ る ${ }^{1) 2)}$ が，この目的には飽和脂肪酸の MS が使用されてい る。すなわちモノグリセリドをアミロースに包摂させてこ の包摂体が老化を抑制するが，明らかに飽和脂肪酸鎖がこ の働きをしている。したがって不飽和度の高い脂肪酸鎖程 包摂は困難になるので，この粘度低下は包摂によるもので はない，そこでアミロースの存在状態を検討した。

\section{4. ヨウ素澱粉反応}

3 種のモノグリセリド中で加熱処理した各種澱粉と生澱 粉のヨウ素澱粉反応を測定し，その $\lambda$ max と Blue value の值を Table 3 に示した.

どの澱粉においても， $\lambda$ max, Blue value 共に生澱粉に 比べて低い值を示した。一般に $\lambda \max$ は澱粉粒に存在する アミロースの長さを表し，Blue value はアミロースの量 を表す.

ウルチ種のとうあろこし澱粉では, Blue value が MS で 81\%, MO で 38\%, ML で 35\% と低下しているものの前述 の粘度程低下していない，特に MLの粘度は相対粘度でほ ぼ $0 \%$ まで低下しているのにアミロースは $1 / 3$ とかなり残 存している．アミロースはアミロペクチンが構成するクラ スター領域（微結晶）中に存在せず，アモルファス領域に 存在すると言われているので，むしろモノグリセリドと接 触し易く，したがって分解がより進むと考えられる。しか し澱粉の粘度は主としてアミロペクチンに影響され，これ が極端に低下したことを考えるとアミロペクチンの方がよ り分解したと考えられる. 無水で加熱処理をしているので アミロペクチンの結晶領域は加熱処理中もそのまま保持さ れているはずであり，モノグリセリドとの接触はアモル ファス領域で起こることになり，したがって分解むアモル ファス領域で起こると考えられる. その結果，極小単位之 してクラスターレベルの大きさに効率的に切断が起きると 推定すれば，著しい粘度低下を説明できる。この点を解明 するためゲルろ過クロマトグラフィー（GPC）で検討した.

\section{5. 分子構造}

前報6) に比べ，今回は粘度低下が著しいことから分解が かなり進んでいると推定し，低分子画分の様子を詳しく知る ためにゲルを前報6) の Toyopearl HW-75F から Toyopearl HW-65F に変更してゲルろ過分析を行った。 3 種のモノグ リセリド中で加熱処理した各種港粉と生澱粉の計 12 種の GPC パターンを Fig. 4-1 に示した. このゲルのグルコー ス（MW=180）の溶出位置がフラクションナンバー（F． N.） 44 であったので，これとゲルの限界排除体積の $0.9 \times$ $10^{6}$ の F.N. 25 を結んだ半対数グラフから各 F.N. の分子量 を算出した。 また，生のとうあろこし澱粉の GPCパター ンのピークの谷間の F.N. 30 が分子量 10 万に相当すること 
Table 2 Viscosity properties of starch heated in monoglyceride

\begin{tabular}{|c|c|c|c|c|c|}
\hline & \multicolumn{3}{|c|}{ Viscosity properties (RVU) } & \multicolumn{2}{|c|}{ Total viscosity (RVU) } \\
\hline & $\begin{array}{c}\text { Peak } \\
\text { viscosity }\end{array}$ & $\begin{array}{l}\text { Minimum } \\
\text { viscosity }\end{array}$ & $\begin{array}{c}\text { Final } \\
\text { viscosity }\end{array}$ & $60-432 \mathrm{sec}$ & $433-780 \mathrm{sec}$ \\
\hline \multicolumn{6}{|c|}{ Normal corn starch } \\
\hline Raw & $25.5(100)$ & $18.1(100)$ & $27.5(100)$ & $890(100)$ & $1910(100)$ \\
\hline Heated in MS & $23.0(90)$ & $15.6(86)$ & $21.3(78)$ & $742(83)$ & $1576(83)$ \\
\hline Heated in $\mathrm{MO}$ & $5.4(21)$ & $1.3(7)$ & $4.0(16)$ & $135(15)$ & $207(11)$ \\
\hline Heated in ML & $0.4(2)$ & $0.3(2)$ & $0.3(1)$ & $28(3)$ & $24(1)$ \\
\hline \multicolumn{6}{|l|}{ Waxy corn starch } \\
\hline Raw & $34.5(100)$ & $14.3(100)$ & $18.4(100)$ & $1467(100)$ & $1438(100)$ \\
\hline Heated in MS & $11.0(32)$ & $9.5(66)$ & $24.3(132)$ & $501(34)$ & $1412(98)$ \\
\hline Heated in $\mathrm{MO}$ & $1.0(3)$ & $0.3(2)$ & $0.5(3)$ & $29(20)$ & $34(2)$ \\
\hline Heated in ML & $0.1(0)$ & $0.0(0)$ & $0.0(0)$ & $2(0)$ & $1(0)$ \\
\hline \multicolumn{6}{|l|}{ Wheat starch } \\
\hline Raw & $24.0(100)$ & $13.0(100)$ & $41.0(100)$ & $695(100)$ & $2280(100)$ \\
\hline Heated in MS & $9.0(38)$ & $5.7(44)$ & $23.5(57)$ & $266(38)$ & $1231(54)$ \\
\hline Heated in $\mathrm{MO}$ & $7.0(29)$ & $2.6(20)$ & $12.8(31)$ & $168(24)$ & $678(30)$ \\
\hline Heated in ML & $2.0(8)$ & $0.4(3)$ & $1.1(3)$ & $35(5)$ & $59(3)$ \\
\hline
\end{tabular}

( ), Ratio to total viscosity $(60-432 \mathrm{sec})$ of raw starch.

Total viscosity is defined as the area of viscosity curve.

Table 3 Iodine color reaction of starch heated in monoglyceride

\begin{tabular}{lcc}
\hline \hline & $\lambda \max (\mathrm{nm})$ & Blue value* $^{*}$ \\
\hline Normal corn starch & & \\
Raw & 591.0 & $0.328(100)$ \\
Heated in MS & 582.8 & $0.267(81)$ \\
Heated in MO & 562.5 & $0.126(38)$ \\
Heated in ML & 559.7 & $0.114(35)$ \\
Waxy corn starch & & \\
Raw & 534.4 & $0.061(100)$ \\
Heated in MS & 532.2 & $0.051(83)$ \\
Heated in MO & 501.7 & $0.025(40)$ \\
Heated in ML & 496.1 & $0.022(37)$ \\
Wheat starch & & \\
Raw & 598.0 & $0.337(100)$ \\
Heated in MS & 591.0 & $0.301(89)$ \\
Heated in MO & 583.3 & $0.284(84)$ \\
Heated in ML & 571.7 & $0.194(57)$ \\
\hline
\end{tabular}

* Blue value is coefficient of absorbance at $680 \mathrm{~nm} / 100$ mg of starch.

( ), Ratio to blue value of raw starch.

から, F.N. 30 までの画分をアミロペクチン (AP) 画分, F. N. 31 以上の画分をアミロース（A）またはアミロース・ア ミロペクチン分解物 (D) 画分とした。 この方式に従い, GPC パターンから算出した結果を Table 4 に示した.

ウルチ種のとうあろこし澱粉では, MS で AP が $13 \%$ （1-65.8/75.5）分解しただけなのに対し，MO では $94 \%$,
ML では $100 \%$ AP が分解し，デキストリン化している，そ して A および D の画分のピーク位置が生澱粉では F.N. 35 に対し，MS ではF.N. 36，MO ではF.N. 37，ML では F.N. 39 と低分子にシフトしている。 また，F.N. 30 以上の 平均分子量をみると $\mathrm{MS}, \mathrm{MO}, \mathrm{ML}$ の順に大きく変化して いる.この傾向はモチ種のとうもろこし澱粉であ同様であっ た.すなわち, MS では AP は $11 \%$ 分解したのに対し, 不 飽和脂肪酸からなるモノグリセリドである MO では $95 \%$, ML では $100 \%$ AP が分解し，デキストリン化している.

これに対し，小麦澱粉の GPCパターンはとうあろこし 澱粉とかなり異なる結果となった。すなわち，MSでは AP が $24 \%$ と分解が進んでいたのに対し，逆にMOでは 25\% と MS とほとんど変わらず，MLでは分解が進んで 98\%であった。

アミロース（A）の分解については A がアミロペクチン の分解物 (D) と溶出位置が重なるため, 定量的に知ること は困難であるが，ウルチ種のとうあろこし澱粉で ML の ピークは明らかに生澱粉の A ピーク位置と離れた低分子 区分にシフトしているので，アミロースもこの処理でかな り分解していることになる，すなわち，MLではどの澱粉 においても平均重合度 (DP) で約 100 前後にまで分解して いると推定されることから，アミロースの DPを 1000 程 度とするとアミロペクチンほどではないがかなり分解して いることになる。しかし，これを Table 3 のヨウ素澱粉反 応の結果と比較すると，アミロースがウルチ種のとうあろ こし澱粉では，ML であ $65 \%$ 減少，小麦澱粉では $43 \%$ 減 少しているに過ぎないことになるので，あまり分解を受け 

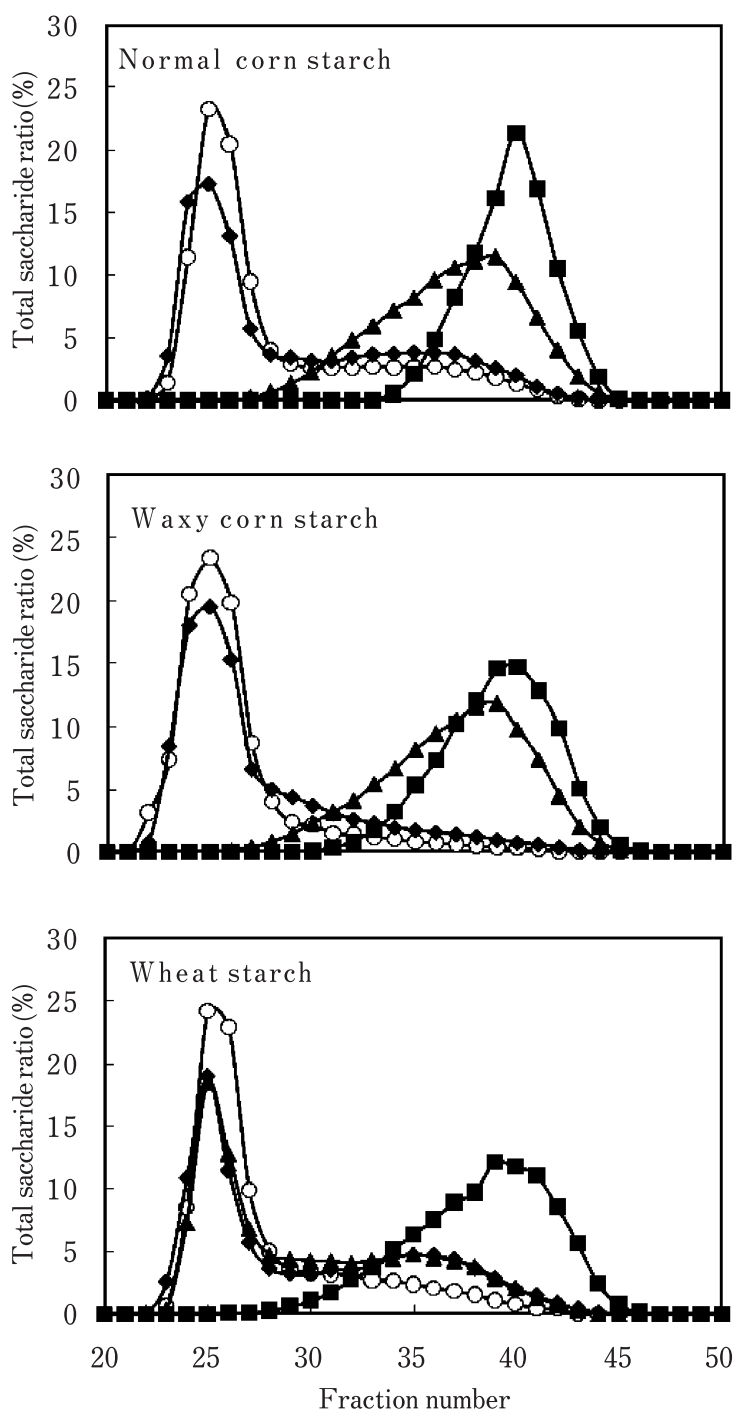

Fig. 4-1 Gel permeation chromatography of starch heated in monoglyceride

Column, $100 \times 26 \mathrm{~mm}$; Gel, Toyopearl HW-65F ; Flow rate, $100 \mathrm{ml} / 60 \mathrm{~min}$

Solvent, $50 \mathrm{mM} \mathrm{NaOH}$; Injection volume, $10 \mathrm{ml}$ (Starch $10 \mathrm{mg}$ ) ; Fraction volume, $10 \mathrm{ml} /$ tube

$\bigcirc$, Raw starch ; $\diamond$, Starch heated in MS

$\boldsymbol{\Delta}$, Starch heated in MO ; $\mathbf{\square}$, Starch heated in ML

ていないものも多いと推定され，両者を合わせて考えると アミロースはかなり不均一な分解をしていると考えられる。

これらの結果を前報6)のクッキーから分離した小麦澱粉 の結果と比較するため, トリパルミチン, トリオレイン, ジクリセリド（エコナ）の 3 種の油脂で調製したクッキー 様試料から分離した分離澱粉を同様に Toyopearl HW-65 F ゲルを用いて GPC を行った結果を Fig. 4-2 に示した. あちろん前報 ${ }^{6)}$ の処理条件 $\left(180^{\circ} \mathrm{C}, 12\right.$ 分処理) は今回の条 件とかなり異なるが，グリセリンの遊離水酸基の役割と飽 和脂肪酸または不飽和脂肪酸と構成要因が異なる場合の相 互比較は可能と考えた.この結果はモノグリセリド処理と

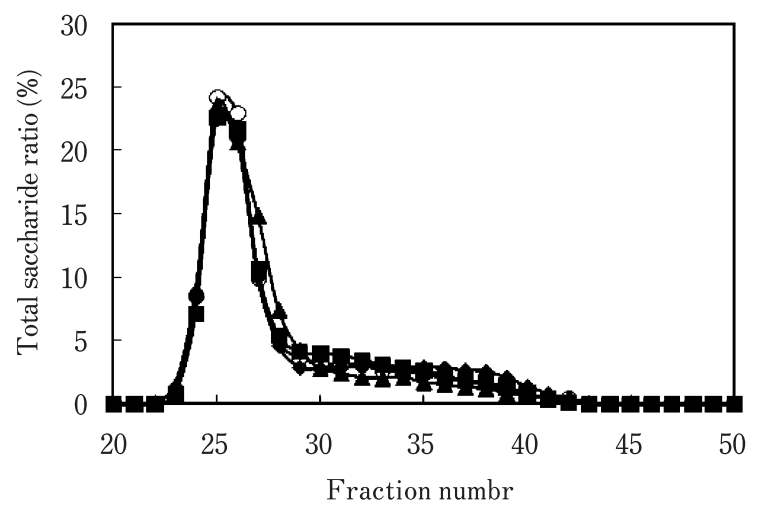

Fig. 4-2 Gel permeation chromatography of starch separated from cookie model samples

Column, $100 \times 26 \mathrm{~mm}$; Gel, Toyopearl HW-65F ; Flow rate, $100 \mathrm{ml} / 60 \mathrm{~min}$

Solvent, $50 \mathrm{mM} \mathrm{NaOH}$; Injection volume, $10 \mathrm{ml}$ (Starch $10 \mathrm{mg}$ ) ; Fraction volume, $10 \mathrm{ml} /$ tube

$\bigcirc$, Raw wheat starch; $\diamond$, Cooked in tripalmitin

$\boldsymbol{\Lambda}$, Cooked in triolein; $\mathbf{\square}$, Cooked in diglyceride(econa)

は全く異なり，分解の程度は飽和脂肪酸と不飽和脂肪酸を 問わずいずれも小さく，また遊離水酸基を 1 個持つエコナ は組成が不飽和脂肪酸であるにも関わらず，トリグリセリ ドと似たパターンであった。

これらの結果を総合的に考えると, 澱粉粒の多次元的組 織体に水酸基 2 個を有するモノグリセリドの形はかなり親 和性が高く, その結果として, 粒組織に容易に侵入して組 織全体に満遍なく浸透し，さらに熱媒体となって澱粉の分 解を進めると考えられる. しかし, 単なる熱媒体ならば, 構成脂肪酸の違いで分解の程度が異なることはないので, 分解に不飽和脂肪酸の二重結合が大きく関与していると思 われる. すなわち，この熱処理が解放系で行われているの で，熱と溶存酸素でラジカルが生成し，これが澱粉分子の 分解を促進すると思われる。しかし，なぜラジカルがグリ コシド結合に選択的に働いて結合を切断するのかは不明で ある。水がほとんど存在しない条件下において熱でグリコ シド結合が切断するときは, 切断部位はアンヒドロ体に なっていると考えられるが，この形成とラジカルの関与は 不明である. とうあろこし澱粉と小麦澱粉の分解の違いは, 澱粉粒の結晶構造の違いでモノグリセリドとアミロペクチ ンの接触に違いがあるかもしれない。一方，とうあろこし と小麦では澱粉にあともと含有している脂質にかなりの違 いがあるので，これが分解の程度に関係することも考えら れるが，小麦澱粉にはリン脂質が多いことを考えるとむし ろこのリンにより分解が促進されるはずであるのに結果は 逆である。したがって澱粉粒に浸透したモノグリセリドが 直接分解を促進したと思われる.

一般に固液 2 相反応では, 固体相と液相との接触面積が 反応速度に深く関与する。したがってこの場合，澱粉粒内 
Table 4 GPC results of starch heated in monoglyceride

\begin{tabular}{|c|c|c|c|}
\hline & $\begin{array}{c}\text { F.N. } 20-30(\mathrm{AP}) \\
\text { Total saccharide ratio }(\%)\end{array}$ & $\begin{array}{c}\text { F.N.31-50 (A } \cdot \mathrm{D}) \\
\text { Total saccharide ratio }(\%)\end{array}$ & $\begin{array}{l}\text { Average molecular weight } \\
\text { F.N.31-50 }\end{array}$ \\
\hline \multicolumn{4}{|c|}{ Normal corn starch } \\
\hline Raw & $75.5(100)$ & 24.5 & $1.0 \times 10^{4}$ \\
\hline Heated in MS & $65.8(87)$ & 34.2 & $6.6 \times 10^{3}$ \\
\hline Heated in $\mathrm{MO}$ & $4.4(6)$ & 95.6 & $4.6 \times 10^{3}$ \\
\hline Heated in ML & $0.0(0)$ & 100.0 & $1.8 \times 10^{3}$ \\
\hline \multicolumn{4}{|c|}{ Waxy corn starch } \\
\hline Raw & $91.4(100)$ & 8.6 & $1.6 \times 10^{4}$ \\
\hline Heated in MS & $81.8(89)$ & 18.2 & $1.6 \times 10^{4}$ \\
\hline Heated in MO & $4.9(5)$ & 95.1 & $4.6 \times 10^{3}$ \\
\hline Heated in ML & $0.1(0)$ & 99.9 & $1.8 \times 10^{3}$ \\
\hline \multicolumn{4}{|l|}{ Wheat starch } \\
\hline Raw & $78.0(100)$ & 22.0 & $1.6 \times 10^{4}$ \\
\hline Heated in MS & $59.4(76)$ & 40.6 & $1.0 \times 10^{4}$ \\
\hline Heated in $\mathrm{MO}$ & $58.8(75)$ & 41.2 & $1.0 \times 10^{4}$ \\
\hline Heated in ML & $2.1(3)$ & 97.9 & $1.8 \times 10^{3}$ \\
\hline
\end{tabular}

(), Relative ratio to total saccharide ratio (F.N.20-30) of raw starch.

へどのようにして脂質が浸透できるかが問題となる，澱粉 の場合, さらに複雑な要因がある。たとえば測粉粒組織に 強固に取り込まれた結晶水は疎水性の脂質の浸透を阻害す るため, トリグリセリド中の加熱澱粉の結果に見られるよ うに，ほとんど伝熱媒体としての働きが主となる。これに 対し，モノグリセリドはかなり親水性むあるので，澱粉そ のものに近づき易く，さらに取り込まれている水之置換し て澱粉分子そのあのと接触できると考えられる．その結 果, 熱媒体としての働きと共に不飽和脂肪酸で形成したラ ジカルが接触している澱粉分子の分解に働いたと考えられ る。したがって，構造的にアミロペクチンの構成単位であ るクラスターのアモルファス領域でこの分解が起きると考 えられるので, 結果的にクラスターを単位とするデキスト リンになるのではないかと思われる。 ウルチ種のとうあろ こし澱粉の MLの GPC パターンがこれを裏付けている. 前報6)で, 粘度をRVA で測定した際ジグリセリドの粘度 低下が大きいことを述べたが，これもトリグリセリドより 親水性が高まったため上述の理由で分解の程度が大きく なったと考えられる。

一般的に糖類はラジカルに安定であるといわれる。した がって，ラジカルそのあのが測粉分子に作用するとは考え 難い。本条件の $150^{\circ} \mathrm{C}$ では一部脱水によるカラメル化も起 きているはずだが，処理澱粉は比較的着色が薄い，した がって, 不飽和脂肪酸のラジカルが 2 次分解して有機酸を 生成し，この酸が澱粉分子の分解の触媒となっているので はないかと考えられる。

\section{要約}

3 種の澱粉（ウルチ種およびモチ種とうもろこし，小麦）
を不飽和度の異なる脂肪酸組成の 3 種のモノグリセリド （ステアリン酸，オレイン酸，リノール酸）中で加熱処理 $\left(150^{\circ} \mathrm{C} ， 1\right.$ 時間）し，その澱粉特性を調べた。その結果，

（1） SEM で澱粉粒の外観は，どの澱粉試料屯変化が見 られず，糊化，膨化していなかった。

（2）DSC の糊化特性では，多価不飽和脂肪酸モノグリ セリド中で加熱処理した澱粉のピーク温度が低下し，エン タルピーも減少した。

（3） RVA の粘度特性では，不飽和度が高いモノグリセ リド中で加熱処理した測粉ほど粘度低下が著しく，特にモ 于種のとうもろこし澱粉では粘性がほとんど消失した。

（4）ヨウ素港粉反応では，不飽和度の高いモノグリセリ ド中で加熱処理した澱粉ほよ゙，アミロースの分解が進んで いた。

（5）GPC の分子量測定では，ステアリン酸モノグリセ リドが軽度しか分解していないのに対し，リノール酸モノ グリセリドでは，デキストリンにまで極端に分解していた。

（6）全ての測定において，ウルチ種のとうもろこし港粉 と小麦澱粉では挙動に差が見られた。

これらの結果から，水分が殆ど存在しない条件下におい て，モノグリセリド中で加熱処理した澱粉は，外観では変 化が見られないが，分子レベルではかなり分解し，特に脂 肪酸鎖の不飽和度がこの分解に大きく関与していることが 明らかとなった。

\section{文献}

1） 日高 徹, 乳化剂の応用, 「食品用乳化剂」, 第 2 版（幸書 房，東京)，pp. 125-234（1991）。

2) Krog, N. and Nybo-Jensen, B., Interaction of monoglycerides in dufferent physical stats with amylose and 
their anti-firming effects in bread. J. Food Technol., 5, 7787 (1970).

3）山田哲也, 糊化と老化,「澱粉科学の事典」, 第 1 版, 不破英 次, 小巻利章, 檜作進, 貝沼圭二編, (朝倉書店, 東京), pp. 193-198 (2003).

4）市川朝子, 中島早枝子, 高脂肪含量クッキーに関する研究 一材料配合抢よび貯蔵条件が性状・糊化度におよぼす影響 一, 家政誌, 36, 935-942（1985).

5）和田淑子, 橋本慶子, クッキー生地作成過程における油脂 の機能，栄食誌，40，505-508 (1987).

6）伊藤友美, 安達卓生, 山田哲也, クッキー様菓子中の澱粉特 性に及ぼす各種油脂の影響, 食科工，55，56-62（2008）。

7) Ito, T., Hasegawa, W., Adachi, T., Kojima, M. and Yamada, T., Effect of Surfactant Addition on Viscosity Profiles of Starches. Scientific Reports of the Faculty of Agriculture Meijo University, 40, 61-70 (2004).

8) Takeda, C., Takeda, Y. and Hizukuri, S., Physicochem- ical Properties of Lily Starch. Cereal Chem., 60, 212-216 (1983).

9) Dubois, M., Gilles, K.A., Hamilton, J.K., Rebers, P.A. and Smith, F., Colorimetric Method for Determination of Sugars and Related Substances. Anal. Chem., 28, 350-356 (1956).

10) Krog, N., Amylose Complexing Effect of Food Grade Emulsifiers. Die Stärke, 23, 206-210 (1971).

11) Lagendijk, J. and Pennings, J.H., Relation between Complex Formation of Starch with Monoglycerides and the Firmness of Bread. Cereal Science Today, 15, 354-365 (1970).

12）岡田 実，糊化と老化，「澱粉科学の事典」, 第 1 版，不破英 次, 小巻利章, 檜作 進, 貝沼圭二編, (朝倉書店, 東京), pp. 193-200 (2003).

(平成 20 年 6 月 23 日受付, 平成 20 年 8 月 13 日受理) 